\title{
Sex and Sexual Attitudes in Seventeenth-Century England: The Evidence from Puritan Diaries
}

\author{
THEODORE DE WELLES
}

Uninhibited revelations about sexual behaviour and sexual attitudes are rare in the diaries of English Puritans writing in the late sixteenth and seventeenth centuries. ${ }^{1}$ For whatever reasons, these works - or "journals." as contemporaries often called them-commonly insist on treating sexual issues with circumspection at best and stubborn silence at worst. This situation is particularly apparent when diarists write about themselves and not about others. Despite the fact that many were married, had large families, and were writing in what has traditionally been considered the most intimate of literary genres, ${ }^{2}$ Puritan diarists, with few exceptions, do not discuss sex in explicit detail.

The discussion which follows is an attempt to explain this silence about sex, to penetrate some of the circumspection and obscurity which surrounds sex in the diaries, and to unearth evidence about how sex was perceived by the diarists themselves. My method will be first to survey the more noteworthy aspects of Renaissance sexual theory as developed by Puritan moralists and select medical authorities, then to discuss what some of the diaries and autobiographies tell us about sex. and finally to explore the problem of silence which arises when these diarists write:

In Shakespeare's Twelfth Night the pleasure-loving Sir Toby Belch taunts the fastidious Puritan Malvolio with the following question: "Dost thou think because thou art virtuous, there shall be no more cakes and ale?" (II.3.124-25). Sir Toby`s remarks typify a popular misconception held by many even today - namely, that Puritanism and pleasure, especially sexual pleasure, were incompatible. English Puritans, however, were not opposed, certainly in theory, to the idea of sexual enjoyment. In fact, they were quite comfortable with it, provided that it was experienced within the boundaries of wedlock. According to many seventeenth-century authors 
of Puritan marriage manuals and domestic conduct books (William Gouge, William Whateley, Thomas Gataker, Daniel Rogers, and others) ${ }^{3}$ couples were expected to marry for three reasons: to reproduce the species, to extinguish the urge to fornicate, and to supply each other with mutual aid and comfort. Sex was considered necessary to fulfill each of these requirements. ${ }^{4}$

To ensure that these requirements were met the writers urge that sex be regular, although they do not always specify what 'regular' means. ${ }^{5}$ In his Matrimonial Honour (1642), Daniel Rogers, for instance, citing Plato as his authority, thought that once a week was appropriate. ${ }^{6}$ It was also argued that sex - or 'due benevolence' as it was sometimes termed - not be deliberately with held by either partner, unless under special circumstances such as during menstruation, pregnancy, or while breastfeeding. ${ }^{7}$ Similarly, husbands and wives were encouraged to sleep together in the same room. Voluntary absences from the marriage-bed, except for reasons of state or business, were seldom tolerated. ${ }^{8}$

Puritan conduct books also offered advice on the proper attitudes spouses should adopt when contemplating or practicing sex. They generally recommended a cheerful and willing disposition, rather than grudging or reluctant compliance. At the same time, however, couples were warned to avoid being motivated by lust - that is, the immoderate desire to have intercourse. Lust was thought to undermine the stability of the marriage contract in a number of ways. It promoted jealousy. Its fire was quickly dampened, leaving behind disillusionment or indifference. And it was regarded as a kind of idolatry, a perverse elevation of the carnal and temporal aspects of marriage over those of the spiritual and divine. ${ }^{9}$

Contrary to what earlier generations of historians have maintained, much of what Puritan writers had to say about sex was neither more original nor more enlightened than the teachings of their early Renaissance predecessors. As Kathleen Davies and others have convincingly demonstrated, Christian humanists such as Erasmus, More, Thomas Elyot, William Harrington, Richard Whitforde, and Juan Luis Vives had formulated identical ideas on sex and marriage nearly a hundred years earlier - ideas which men like Gouge and Whateley would later repeat. ${ }^{10}$ The only real difference between the two groups and their teaching resides in the Puritan rejection of the residual medieval notion, articulated by Harrington and others, that "voluntary sexual abstinence among married couples was a means of obtaining grace."11 Puritan moralists opposed this view. For them, the full realization of an individual's human and spiritual potential was best accomplished not by withdrawing from the physical side of wedlock, but by embracing it wholeheartedly. A sermon delivered at a marriage ceremony by the New England preacher John Cotton provides an effective illustration of this position. Cotton tells the story of a 
newly married couple who agree to refrain from sex:

[the husband] who immediately upon Marriage, without ever approaching the Nuptial Bed, indented with the Bride, that by mutual consent they might both live such a life, and according did sequestring themselves according to the custom of those times, from the rest of mankind, and afterwards from one another too, in their retired Cells, giving themselves up to a Contemplative life; and this is recorded as an Instance of no little or ordinary Vertue; but I must be pardoned in it, if I can account it no other than an effort of blind zeal, for they are the dictates of a blind mind they follow therein, and not of that Holy Spirit, which saith It is not good that man should be alone. ${ }^{12}$

But while Puritan moralists pay considerable attention to the theoretical side of sex, they are resoundingly mute on the subject of specific sexual procedures and behaviour. One looks in vain through their works for explicit guidance on sexual problems or for discussions of sexual technique and positions - a noticeable contrast to many medieval penitential guides, which itemized sexual transgressions in rather obsessive detail. ${ }^{13}$ According to Kathleen Davies, the only Puritan work which comes close to giving practical instructions is William Heale's The Great Advocate and Oratour for Women (1682), a pamphlet which suggests the use of sex as a way for mistreated and neglected wives to reawaken their husband's slumbering desires. But even here the writer is vague, cryptically counselling women to invite their spouses to walk with them "into this Temple of Eroto (or the Muse of Love) which is erected for your sakes alone."14

By comparison, the authors of Renaissance medical treatises seem more frank than the domestic moralists. Thomas Cogan maintained that sex promoted good health, but did so only under certain conditions. Considering it unhealthy to have coitus after a meal, he suggested morning as the ideal time, after which he advised taking a brief nap. William Vaughan thought differently. For him, sex was most beneficial when performed at night, "when the stomack is full, and the body somewhat warme." However, he agreed with Cogan about the need for sleep immediately afterwards, arguing that rest was a necessary remedy for "the lassitude caused through the action thereof." 15

Some medical tracts furnish even more precise advice, although it is admonitory in character. It was proposed in one text, for instance, that because a male's semen had to be emitted in a straight line for conception to occur, couples should avoid "Apish waies and manners of Copulation." 16 Other works are less prohibitive. The popular medical handbook, Aristotle's Masterpiece (1690), urged couples to disengage from each other slowly after coitus, in order not to interfere with the process of conception. For the same reason it also advised women to refrain from coughing or sneezing immediately after intercourse. ${ }^{17}$ 
The Puritan moralists' avoidance of the logistical aspects of sex repeats itself in the personal diaries and autobiographies of other Puritans. ${ }^{18} \mathrm{We}$ should not conclude, however, that Puritan journals ignore the topic of sex altogether. They do not. In fact, sexual issues and incidents surface with some measure of regularity, but they often do so in an oblique and unelaborated fashion. In addition, the context in which they appear is almost always a moral one. That is, sexual experience is treated as one of the ways an individual can measure his or her spiritual progress and lapses.

This is a crucial point. In a society where oral confession was no longer recognized as a valid mechanism for spiritual purgation and renewal, the daily examination of moral conflicts, defeats, and victories assumed considerable importance among godly men and women. Denied the assurance of salvation (or perhaps its illusion) which auricular confession had conferred upon an earlier generation of believers, many English Protestants increasingly sought that assurance through disciplined, systematic selfinterrogation. The form this interrogation took was generally that of a diary, and it served a multitude of spiritual functions: to foster an awareness, painfully and gradually earned, of the subtle corruptions of the human heart; to reinforce the knowledge that one's soul is being constantly beset by evil forces threatening to destroy it: and to convey the sense that issues of the most profound spiritual import often inhabit the most mundane aspects of human experience. It was only by devoting a lifetime to rigorous self-analysis, replete with the insights gained from personal temptations, doubts, struggles, and joys, that the Puritan diarist might hope to be assured of salvation. Even then assurance might not be forthcoming, since it was conferred by God only upon a select few. Nor was it always deemed absolutely necessary for salvation. In the event. however. that God did choose to bestow assurance. it was generally believed that such a gesture only came about through sustained and strenuous internal scrutiny. ${ }^{19}$

It was precisely for this reason that diarists were enjoined to record not only their sins and temptations, but also their deliverances by God from these and other th reats. By recording and recollecting God's daily mercies. diarists fortified themselves against lack of spiritual steadfastness, ingratitude, and despair, and were emboldened in their quest for assurance. This explains why so many Puritan journals are filled with examples of narrow escapes from danger and sudden visitations of good fortune. On one day alone - 26 January 1637/8 - Robert Woodforde, the Puritan steward of Northampton, thanked God in his diary for helping him find his way out of a forest, for receiving $11 \mathrm{~s}$. in payment for some legal work, for obtaining an additional $£ 6$ as a loan to pay off a debt, and for his safe passage over a bridge "in the great water where I did not well know the way." 20

Deliverance from evil, therefore, came to be seen as one of the possible 
signatures of Divine election. John Beadle, the author of a popular handbook on diary-keeping entitled The Journal or Diary of a Thankful Christian (1656), develops this point at some length:

It is good to set down every affliction we have met with in our time, and to observe Gods carriage towards us in them, with the benefit we receive from them ... And indeed, what is our whole life, but a continual deliverance? We are daily delivered either from the violence of the creature, or the rage of men, or the treachery of our own hearts, either our houses are freed from firing, or goods from plundering, or our bodies from danger, or our names from reproaches, or our soules from snares. This being the difference betwixt a gracious and a graceless heart; a godly man is delivered, a wicked man is but reserved. God knows how to deliver the godly out of temptations, and to reserve the unjust unto the day of judgement, to be punished. ${ }^{21}$

The dense moral and providential context within which Puritans conducted their self-examination therefore guaranteed that even the most minute and private details of life became events of ultimate significance. Given such a framework, something as common as resisting a carnal urge took on the hue and texture of a major spiritual victory. By the same token, experiencing an erotic dream might be viewed as a disturbing sign of moral depravity.

In light of the Puritan tendency not to deny any facet of human experience the status of a momentous moral occasion, one can only react with puzzlement to the diaries' enigmatic approach to sex. In matters pertaining to a writer's own sexual experiences, Puritan journals are almost unanimously circumspect. Nothing they contain approaches the casual and candid revelations we find in the diaries of, say, Simon Forman, Pepys, or Boswell.

Nowhere is this circumspection more in evidence than when the diarists write vaguely about their "temptations," "troubles," "evil thoughts," or "sins." Whether or not these terms have sexual connotations is difficult, if not impossible, to determine with any degree of certainty. But the inclination of many writers to name their other sins - anger, drunkenness, laziness, greed, worldliness - suggests that at least some of these more obscure references may indeed have a sexual dimension.

Robert Woodforde, for instance, refers to a particular unnamed offense in his diary which he suspiciously designates "that sinne." On 6 November 1638 he writes how he prayed "against that sinne which I had much strife \& conflict with this morning \& some dayes before." This might be the same sin Woodforde mentioned a few months earlier when he asked God to keep him "from all sinnes especially that sinne for the Lordes sake." 22 A similar but more mysterious event in Woodforde's life took place before he even began keeping his diary - when he was about twenty-eight years old and unmarried..$^{23} \mathrm{He}$ writes about an episode that transpired three years to 
the day before the following entry, dated 16 October 1637 :

I came alonge with Mr Bullivant to Northampton, and I declared to him in private the temptacion which began vppon me this day 3 yeares. Oh Lord I blesse thee for thy wonderfull mercye in carryeinge me through it. I beseech thee that I may never forget thy goodnesse to me in this but that I may labour to be truly thankfull \& to expresse thankfullnes by more fruitfull walking for the Lordes sake Amen.

One year later, on the same date, Woodforde again commemorates his deliverance from this unspecified temptation, observing that exactly four years earlier "an occasion of much sorow \& temptacion" had befallen him. ${ }^{24}$ Woodforde's reluctance to divulge the contents of this temptation is perplexing, especially since he is so candid about some of his other failings - such as his rash anger and his tendency to drink too much. Whatever his motives, he has chosen not to share the secrets of this apparently traumatic ordeal with his diary or with us. ${ }^{25}$ Adam Eyre, a Yorkshire yeoman who fought with Fairfax during the Civil War, is equally coy about some of his temptations. His diary reveals that on 15 August 1647 he laboured under "a sore temptation all day." ${ }^{26}$ Only Dr. Samuel Ward, master of Sidney Sussex College at Cambridge, employs less cautious language, confessing that in 1595 he occasionally was guilty of "adulterous" and "incontinent" thoughts. ${ }^{27}$

Aside from revelations like Ward's, the dearth of detail which accompanies these isolated entries renders any claim that they deal with sexual experience a problematic one. But when sufficient information is available, making it possible to assemble a more precise context, the vagueness is somewhat dispelled. It seems, for example, that several male writers underwent "sore temptation" when separated from their wife or when their wife was pregnant - a condition which, as we have seen, theoretically put a stop to sex. The Essex clergyman, Ralph Josselin, found himself afflicted with "roving thoughts" while his wife was visiting London in the spring of 1669. ${ }^{28}$ During a similar separation from his pregnant wife in July 1638, Robert Woodforde confesses he had to battle "evill thoughts," "corruption," and a troublesome heart which he likened to a "raginge boylinge sea." 29 We should not discount the possibility that these men may be expressing sexual frustration and anxiety brought on by the prolonged absence of their spouses.

Diarists also betray anxiety about their dreams, many of which appear to have been sexually arousing. Samuel Ward notes at least two "adulterous" dreams he experienced, one of which he suggests may have been provoked by a woman of suspect virtue who had visited the rooms of the Trinity College students earlier in the day. ${ }^{30}$ Henry Newcome, a Lancashire Presbyterian, writing soon after the Restoration, similarly 
complains several times in his diary that his mind was being "basely poisoned" and "basely polluted" by "base" dreams at night, phenomena which he blames on Satan. ${ }^{31}$

Both Ward and Newcome explain the causes of their dreams in terms that would have been familiar to contemporaries. Thomas Newton's translation of Levinus Lemnius' The Touchstone of Complexions (1576) maintained that sexual dreams were the combined result of secret desire and a superfluity of seminal fluid, an interpretation that corresponds at least in part to Ward's own diagnosis wherein he implies a correlation between his dream and the nameless woman at Trinity. Lemnius explains it thus:

...they whose Genitoryes and priue partes be swelled with stoare of
excrementall Seede and spermatike Humour, or in the daye tyme did earn-
estly fixe their eyes and mynde vppon any beautifull and fayre yonge
Woman, do in their Sleepe thinck themselues to enioy their desyred pur-
pose, and throughe imaginatiue dealinge wyth her, defyle themselues wyth
nightlye pollutions. For the Soule (when the body is in sounde Sleepe, and
al the outwarde senses at rest) wythdrawinge it selfe into the innermoste
partes of the body, perceyueth, vnderstandeth, \& beholdeth those actions
which ye body is to do by day. ${ }^{32}$

Henry Newcome's acknowledgement that Satan could be behind erotic dreams was likewise a commonplace of seventeenth-century thought. The great Quaker diarist, George Fox, noted in his journal that dreams derived from three causes: worldly affairs and business, divine communication with the dreamer, and the "whisperings of Satan in man in the night season." 33

But the most remarkable dream surely belongs to Richard Norwood, the well-known surveyor of the Bermuda Islands and a strict Puritan. In his journal (begun in 1639 and which is more properly an autobiography than a diary) Norwcod gives the following account of a dream he had while visiting Italy in 1610 , when he was twenty years old:

Oft-times I verily thought that I descended into Hell and there felt the pains of the damned, with many hideous things. Usually in my dreams me thought I saw my father always grievously angry with me... And sometimes I seemed to see a thing on my breast or belly like a hare or cat, etc: whereupon I have sometimes taken a naked knife in my hand when I went to sleep, thinking to strike at it ... ${ }^{34}$

The dream is remarkable because it is a manifestation of the guilt Norwood felt over the regular practice of what he elsewhere terms perhaps intending a pun - his "master sin," masturbation. ${ }^{35}$ The image of the angry father and the detail about sleeping with a knife certainly suggest, even to someone unfamiliar with the nuances of Freudian psychology, a guilt-ridden mind at work. In addition, Norwood himself admits 


\section{2 / Renaissance and Reformation}

that such dreams, or "mares" as he calls them (periods "wherein a man seems to be neither quite awake nor quite asleep") were frequently accompanied by "nocturnal pollutions." $36 \mathrm{He}$ means, of course, seminal emissions.

Norwood's "nightly disease" seems to have started during his stay in Italy - interestingly enough, at a time when he had temporarily converted to Roman Catholicism. It persisted for the next six years until he was twenty-six, at which time (1616) he returned to the Protestant faith. But even then he was not wholly free of its bondage, admitting in his journal (which he wrote until he was nearly fifty) that he still was "troubled with that disease unto this day, but seldom and remissly, I give thanks, as three or four times a year." 37

The significance of Norwood's experience with masturbation, however, extends beyond his decision to write about it. For Norwood does not merely record, he also interprets and his interpretation is intriguing indeed. According to Norwood masturbation is not just a sin. but a weapon God wields to shock him out of spiritual complacency and pride. Thus when Norwood, encouraged by the successful suppression of his urge for a few weeks, vows to abstain forever from his "master sin" he discovers to his shame that God deliberately brings about a relapse. Masturbation in these circumstances becomes, therefore, a punishment visited upon Norwood for his presumption in attributing the initial success of his abstinence to his own strength and resolution and not to God's grace. ${ }^{38} \mathrm{~A}$ lesser offense illuminates the sinner's perception of a far greater transgression - the sin of pride. And through that painful process the sinner himself grows in spiritual understanding:

... I like a wretch. did not give God the glory but thought I did it in my own strength. with some general kind of assistance. And afterwards finding such success in a vow. I vowed to abstain from that master sin forever, but shortly after fell into it again. Now I was not careful to make good use of this breathing time of freedom which the Lord vouchsafed me, but seemed pretty well that I was freed (and thought) from that master sin, and I believe should have contented myself with that; therefore it was just with God and a mercy he was pleased to make it to me too, to let me fall again into the same sins, as indeed I wretchedly did often after this. ${ }^{39}$

Norwood's capacity to put masturbation into perspective, and to see it as a relatively minor offense was not without precedent. Several contemporary medical texts, for example, generally adopt a tolerant, or at least a morally neutral, attitude toward the subject. ${ }^{40} \mathrm{~A}$ few works even went so far as to advocate masturbation on the grounds that excessive accumulation of seed was physically and psychologically harmful. ${ }^{41}$ Some moral treatises, on the other hand, condemn the practice outright. Robert Allen's A Treasvrie 
of Catechisme, or Chrstlaan Instrvction (1600) denounced anyone who "worketh filthinesse alone with himselfe, and is defiled in his body." ${ }^{42}$ But as a rule, the moralists tread gingerly over the whole issue.

A cautious course is also taken by Puritan diarists when they write about youthful masturbation. They allude to it with their typical obscurity. Nehiamiah Wallington, a seventeenth-century London artisan, claimed vaguely that "lust," his most delightful sin, had afflicted him since he was eight years old.$^{43}$ Ralph Josselin is equally ambiguous, saying merely that as a child God's grace had restrained him "from lewdnes" and had rescued him from the "many untowardnesses" to which young boys are prone. ${ }^{44}$ The only forthright confession of masturbation, aside from Norwood's, comes from George Trosse, the Nonconformist minister of Exeter in the late seventeenth century. Like Norwood, Trosse wrote an autobiography, not a diary, in his later years. Like Norwood too, his first recorded encounter with the sin took place in a foreign and predominantly Roman Catholic country, Portugal. Trosse was sixteen at the time (1647), about four years younger than Norwood was when his masturbatory experiences began. $\mathrm{He}$ writes in his autobiography that while living as an apprentice among English merchants in Oporto, a "lewd Fellow-Servant led me to practise a Sin, which too many Young Men are guilty of, and look upon it as harmless; tho" God struck Onan dead in the Place for it." 45 In contrast to the coyness shown by the diarists, this disclosure is refreshingly frank. What it lacks, however, is the introspective scrutiny and spiritual sophistication which Norwood brings to bear upon the subject.

When diarists turn from discussing their own sexual experiences and comment instead on the sexual misbehaviour of others, they become somewhat more explicit. The sexual conduct they observe, however, is almost always illicit, deviant, or sensational, and acts to reinforce the diarists' conviction that those who participate in such activity are not among the godly elect ${ }^{46}$ In this respect, sex functions as a way of assuring the writers of their own special status in God's eyes, if only by pointing out to them the dissolute lives of the reprobate masses.

Several diarists find it difficult to refrain from this kind of judgmental assessment. Thus Lady Grace Mildmay, a Northamptonshire gentlewoman who kept a journal from 1570 to 1617 , finds scandalous the "licentious behaviour" and "monstrous spectacle" of a local commonlaw couple and resolves to "abhor and despise" such people. As a girl she was warned to "avoyd the company of serving men, or any of lyke disposition, whose ribald talk and ydle gestures and evill suggestions were dangerous for our chaste ears and eyes to hear and behold." 47 Robert Woodforde writes in March 1637 about how one of his fellow townsmen was jailed for keeping company with a "naughty woman," concluding the entry with a prayer thanking God for graciously sustaining him on the path of righteousness. ${ }^{48}$ And Simonds 
D'Ewes discloses that as a student in 1620 at St. John's College, Cambridge, sodomy was so rampant among his classmates that he was "fain to live almost a recluse's life, conversing chiefly... with some of the honester fellows thereof." 49

Clearly, the recording of illicit and deviant sex in others was not done purely out of salacious interest in the bizarre or unconventional. ${ }^{50} \mathrm{On}$ the contrary, it helped to affirm diarists in their own sense of superior moral virtue and gave them the opportunity to acknowledge God's power in maintaining them in that virtue.

As well as helping us grasp what Puritans may have thought about sex, the journals occasionally reveal the extent to which the sexual activities of Puritans actually conformed to traditional moral precepts. On the whole, of course, seventeenth-century diaries seem to lack the kind of data needed to calculate how often people had sexual intercourse or how they went about exciting each other erotically. In these areas diaries rarely, if ever, provide verification or modification of the moralists' position that the frequency and manner of intercourse should be tempered by the principle of moderation. There is one area, however, where diaries can be informative. Alan Macfarlane has found evidence in Ralph Josselin's diary which indicates that Josselin and his wife had sexual relations while she was still nursing - a violation of the traditional taboo against intercourse during lactation. ${ }^{51}$ Two months before their youngest child was weaned, Mrs. Josselin told her husband that she was seven weeks pregnant. She was probably mistaken, for no subsequent birth or miscarriage is recorded. Nevertheless, the fact that Mrs. Josselin believed herself to be with child proves that she and her husband had begun to have sex prior to the termination of the suckling period. In such instances, then, diaries can be useful tools in revealing to what degree the moralists' advice on certain aspects of sexual protocol was followed. ${ }^{52}$

Diaries can also help us ascertain the kinds of sexual information to which Puritans had access. Lady Mildmay, to cite just one example, related in her journal that as a child she was encouraged by her governess, a woman possessed of "good knowledge in phisick and surgerie," to read medical and botanical works like John Vigon's The Most Excellent Workes of Chirurgerye (1543) and William Turner's Herbal (1568). Her early exposure to these and similar texts accounts for Lady Mildmay's interest in medicine as an adult. Every day, we learn, she "spent some time in the Herball and books of phisick, and in ministering to one or other by the directions of the best phisitions of myne acquaintance." 53

What she read is illuminating. Vigon's book contains a concise medical description of the male and female reproductive organs - the "yard" (penis), the "stones" (testes), and the "matrice" (womb). Its portrayal of a woman's sexual organs and their operation is traditional insofar as it 
considers them to be hidden replica of male genitalia - a notion whose popularity and authority can be traced back to at least the time of Galen, who is commonly credited with formulating the most enduring model of human reproduction prior to the Enlightenment. Thus the vaginal canal, including the clitoris, was thought to correspond to a man's penis, while the ovaries were likened to his testicles. Given such a model, it was natural enough to develop the argument that conception could only take place when both partners achieved orgasm. The logic was straightforward. Since men had to ejaculate in order to reproduce, women had to as well. This idea - the two-seed or semence theory - governs Vigon's remarks about the womb:

The matrice ... hath also two ventricles, which ende at one mouth, and it hath lytle additions of flesh called the two hornes of the matrice, and behynde them the two stones of a woman ben situated. And ye sayde stones ben smaller and broder than a mans, but they ben not so long. And the seed of a woman descendeth to them through the myddest of the matrice. ${ }^{54}$

In short, Lady Mildmay, along with many other seventeenth-century women, was expected and encouraged to feel - and receive - sexual pleasure during intercourse with her spouse..$^{55}$ Pleasure was the only reliable gauge of female orgasm, without which, so the medical theorists maintained, conception was impossible. ${ }^{56}$ Unlike some of her Victorian counterparts, the last thing this Puritan gentlewoman experienced during sex was revulsion. ${ }^{57}$

The other book mentioned by Lady Mildmay, Turner's Herbal, also discusses sexual matters, but does so within the context of popular plant lore. Among its many cures for physical ailments is a herbal remedy - "clary" which alleviates male sterility. Turner promised that it would "stirreth men to the getting of childer." Coriander, he claimed, "increaseth the sede" in men, but he advised using it in moderation lest overuse bring on madness. Should a woman wish to enhance her own sexual appetite, he suggested she employ a mixture which included rue. ${ }^{58}$ Lady Mildmay may never have used these aphrodisiacs, but she knew about them. And we know she knew about them by reading her journal. ${ }^{59}$

In spite of the evidence thus far surveyed, the fact remains that Puritan diarists generally are tight-lipped about sex. They talk about it here and there, especially when it takes the form of a personal temptation or is perceived as a sign of moral degeneracy in others. But seldom does it become a subject for sustained discussion, penetrating analysis, or candid revelation.

This is not the case with spiritual autobiographies. Richard Norwood 
and George Trosse, as we have seen, are quite open about such highly personal sexual experiences as masturbation. Nor do they shrink from acknowledging their attraction to and involvement in other kinds of prohibited sexual activity - fornication, for instance. Trosse admits that while in Portugal he was "haunted with lascivious Speeches, Gestures and Actions without, and with impure Fancies within." 60 This should not suggest, however, that Norwood and Trosse are simply more honest or less inhibited than diarists like Robert Woodforde or Henry Newcome. The reasons for their apparent candour proceed from the genre in which they are writing. not necessarily from their personalities.

Since at least the time of Augustine, whose Confessions established itself as a paradigm for this kind of discourse, one of the hallmarks of the conversion narrative was an emphasis on the morally squalid life of the individual prior to his or her spiritual rebirth in Christ. Within this genre sins of the flesh were accorded a prominent place among the misdeeds from one's reprobate past. Augustine himself declares that throughout his adolescence he had been awash "in the broiling sea of my fornication," impelled to chart a course devoted "entirely to lust." 61 We should not, therefore, be surprised to find both Trosse and Norwood (the latter reveals in his journal that he had read the Confessions) reporting their sexual transgressions in a rather frank manner. ${ }^{62}$ They, along with other Puritan autobiographers, are merely following the Augustinian model. ${ }^{63}$

It has been suggested that this procedure encouraged writers to exaggerate their sins and thereby disqualifies. or at least mitigates, the validity of their testimony. ${ }^{64}$ Precisely the reverse may be the case. The conventionalization of sexual experience which the conversion narrative promoted might very well function as a sanctioning mechanism, allowing autobiographers the liberty to reveal potentially shameful episodes from their past with less restraint and less circumspection than they might otherwise have done.

Unfortunately, the same cannot be said about the diarists, whose works all too often resist efforts to unveil their sexual secrets. This silence has several explanations. Certainly. one of the most understandable is the writer's fear that the diary would be read by strangers. To guard against this many dia rists sometimes chose not to write in English. Samuel Fairclough is said to have kept a diary in both Greek and Latin. ${ }^{65}$ Simonds D'Ewes wrote his in cipher. ${ }^{66}$ Others destroyed their diaries or ordered in their wills that they be destroyed. ${ }^{67}$ Robert Woodforde took perhaps a more credulous approach. He inscribed a plea on the cover of his journal which read simply: "who ever findes this book (if lost) I pray be sparinge in looking into it and send it to Robert Woodforde at Northampton." 68

The fear of discovery and of subsequent misinterpretation was not unfounded. Henry Newcome recounted in his journal on 3 November 
1665 , the story of how his fellow dissenter, Mr. Steele, had his diary confiscated and read by others. Steele apparently wrote that on a certain day he had intended to perform some "carnal" business. His enemies, seizing upon the word "carnal," concluded that Steele had planned a sexual liaison with a woman. In reality, Newcome informs us, Steele was talking about going to a fair to buy a cow - "carnal" business here meaning "worldly," not "sexual," business ${ }^{69}$ Failing in his objective, he then "went home with a gentlewoman, and they had some opportunity for the soul together," which Newcome - and we have no reason to doubt him unhesitatingly interprets as godly conversation and instruction. ${ }^{70}$ The episode tellingly underscores the fact that it did not pay in some instances for diarists to be too frank about their personal affairs, sexual or otherwise. Discovery by one's foes was a real and dangerous possibility, especially for nonconformist clergy like Newcome and his colleagues during and immediately after the Restoration. ${ }^{11}$ Of course, Puritans were perfectly capable of playing the same game. In 1643, when Archbishop Laud was tried before Parliament on charges of high treason, a prime piece of evidence used against him was his own diary. ${ }^{72}$ William Prynne, Laud's old antagonist, even went so far as to publish extracts from it. One of these, an ambiguous entry in which Laud confesses dreaming that he and the Duke of Buckingham were in bed together, prompted Prynne to accuse the prelate of "uncleaness." 73

But there is an even more compelling motive for the diarists' silence about sex, especially married sex. As I have already mentioned, the development of humanism and the Reformation had rendered sex within marriage theologically respectable. Certainly, by the seventeenth century it had ceased to be regarded, as it had been during the Middle Ages, as a barrier to achieving a higher form of spiritual perfection.

One has only to consider the case of the fifteenth-century English mystic, Margery Kempe, in order to realize how profound this shift in attitude was. In her autobiography, Margery is anything but silent about sex. She talks candidly and at length about her physical relationship with her husband, confiding on more than one occasion that his sexual overtures fill her with loathing and that she complies only out of wifely duty:

... sche had neuyr desyr to komown fleschly wyth hyre husbonde, for pe dette of matrimony was abhominabyl to her pat sche had leuar, hir thowt, etyn or drynkyn pe wose, pe mukke in pe channel, pan to consentyn to any fleschly comownyng saf only for obedyens. \& so sche seyd to hir husbond, 'I may not deny zow my body, but pe lofe of myn hert \& myn affeccyon is drawyn fro alle erdly creaturys \& sett only in God.' He wold haue hys wylle, \& sche obeyd wyth greet wepyng \& sorwyng for pat sche myght not levyn chast. $^{74}$ 
Margery writes freely about sex because she was disturbed that it prevented her from attaining true holiness through celibacy, a calling which Ambrose, Jerome, Augustine, and later medieval moralists had deemed superior to married sexuality. Jerome even proclaimed that a fundamental incompatibility existed between the sexual and spiritual worlds. ${ }^{75}$ Thus Margery desperately yearns to dedicate herself wholly to her Saviour; yet she recognizes this will never be possible as long as her "vnclennesse" with her husband continues. So she exacts from him a promise that he will "asken no dett of matrimony." 76 Only by putting off the harness of marital intercourse can she assume the raiment befitting a bride of Christ.

But in the sixteenth century, marriage and marital sex ceased to be a source of frustration among godly individuals. Far from impeding people in their quest for a more perfect relationship with God, sex within marriage came to be looked upon as a means to advance that quest, controlling an individual's sinful passions and thereby better preparing him or her for salvation. ${ }^{77}$ This view had currency in England as early as 1532, when Richard Taverner published his translation of Erasmus' Encomium Matrimonii:

... no where ye may fynd the purenes and perfection of maners les spotted and contaminate, than amonge wedded persons. Let the swarmes of monkes, fryers, chanons, \& nunnys auaunce theyr professyon as moch as them lust. Let them bost as moch as they wyll, theyr cerymonyes \& dysguysed cotes ... suerly the most holy kynd of lyfe is wedlocke puerly \& chastly kept ... For what thynge is sweeter then with her to lyve, with whome ye may be most streghtly copuled, not only in the benevolence of the mynd, but also in the coniunction of the body. ${ }^{78}$

The position developed by Erasmus and other humanists maintained its currency well beyond the early stages of the Reformation. Protestant moralists continued to devalue the idea of celibacy, especially after the Council of Trent (1545-63) had reaffirmed its spiritual ascendancy over marriage and thereby solidified its place as an abiding feature of Catholic doctrine. ${ }^{79}$ By the seventeenth century, Puritan writers were vigorously advocating the primacy of sexual, wedded love. Gouge, for example, exploits the rich, erotic overtones of Proverbs 5:18-19 when he addresses the subject:

Rejoyce with the wife of thy youth: Let her be as the loving Hind and pleasant Roe, and be thou ravished always with love.

Gouge highlights his remarks with the observation that the hind and roe are apt symbols of married affection because they are the animals most "enamored ... with their.mates, and even mad againe in their heat and desire after them." 80 
Other moralists followed suit, arguing that contrary to the medieval and Counter-Reformation position, celibacy hinders spiritual growth because it cannot check sexual appetites, only inflame them. The result is lust. ${ }^{81}$ Marriage, on the other hand, channels sex into a creative drive that manifests itself in the mutual love of husband for wife and wife for husband - a physical and spiritual bond which ultimately glorifies God. The ultimate poetic expression of this sentiment is, of course, Milton's great paean to wedded love in Book IV of Paradise Lost. ${ }^{82}$ Thomas Gataker renders the idea in more prosaic terms:

... let both man and wife so esteeme either of other, as joyned by Gods counsell, as given by Gods hand; and so receive either other as from God, bee thankfull either for other unto God, seeke the good either of other in God; and then will God undoubtedly with his blessing, accompanie his gift to his owne glorie, and their mutuall good. ${ }^{83}$

And Robert Woodforde utters a virtually identical thought to mark the occasion of his thirty-fourth birthday. On 3 April 1640 he thanked God for joining him and his wife "both together long to thy glory \& our mutuall comfort."

The silence of Puritan diarists on the subject of sex, therefore, is not necessarily the silence of shame, or guilt, or fear. Rather, it is the silence of assurance - an assurance that ardent love, physically manifested, is indispensable in forging the bonds of reciprocal affection, aid, and comfort which ultimately unite couples not just to each other but to God as well. Ironically, the assurance which many Puritans so anxiously sought through their recording of daily experience, was rarely lacking whenever they entered the bedchamber with their spouse.

\section{Records of Early English Drama, University of Toronto}

\section{Notes}

1 The terms "Puritan" and "Puritanism" are the subjects of much scholarly debate. For the purpose of this study Puritan diarists are considered those individuals who exhibit one, several, or perhaps all of the following traits: a belief that the English church should be minimally ritualıstic, non-episcopal, and gospelpreaching in its structure and orientation; a recognition of the need to examine regularly one's own inner, spiritual condition in order to determine its conformity to divine will and precept; a strong awareness of personal guilt due to sin; a preoccupation with spiritual salvation often accompanied by anxiety or doubts of attaining it; a sense of being spiritually distinct from other members of English society, who were commonly viewed as ungodly or irreligious. This list is by no means exhaustive. Nor is it meant to suggest that there existed a coherent, uniform body of belief shared by all men and women who have since come to be designated as "Puritans." All of the diarists, however, whose works were examined for this study reveal at least one of the above characteristics.

For a more extensive treatment of the problems and complexities in defining Puritanism see: G. E. Aylmer, "Collective Mentalities in Mid Seventeenth Century England: I. The Puritan Outlook," Transactions of the Royal Historical Society, 5th series, 36 (1986), 1-25; C. 


\section{0 / Renaissance and Reformation}

H. George, "Puritanism as History and Historiography," Past \& Present, 41 (1968), 77-104; Richard L. Greaves, Society and Religion in Elizabethan England (Minneapolis: University of Minnesota Press, 1981), pp. 3-14 and passim; Basil Hall, "Puritanism: the Problem of Definition," in Studies in Church History, vol. 2, ed. G. J. Cuming (London: Thomas Nelson and Sons, 1964), pp. 283-96; Christopher Hill, Society and Puritanism in Pre-Revolutionary England (Harmondsworth, Middlesex: Penguin Books, 1986), pp. 15-30; and John Morgan, Godly Learning: Puritan Attitudes towards Reason, Learning and Education, 1560-1640 (Cambridge: Cambridge University Press, 1986), pp. 9-22.

2 A recent study which explores the issues of intimacy and secrecy in diary-writing is Lawrence Rosenwald, "Some Myths about Diaries," Raritan, 6(1987).97-112. Rosenwald argues against the popular belief that diaries are private texts.

3 A list of the major Puritan writers who dealt with the subject of marriage is provided by Kathleen M. Davies in "The Sacred Condition of Equality - How Original Were Puritan Doctrines of Marriage?" Social History. 2 (1977), 564, n. 3.

4 The ends of marriage were officially set forth in the Book of Common Prayer (1549) and were repeated with little variation by those Puritans who wrote on the subject. See Kathleen Davies, "Continuity and Change in Literary Advice on Marriage," in Marriage and Society, ed. R. B. Outhwaite (London: Europa Publications, 1981).p. 62 and William and Malleville Haller. "The Puritan Art of Love," Huntington Library Quarterly. 5(1941/42), 239. Edmund Leites. The Puritan Conscience and Modern Sexuality (New Haven.CT.: Yale University Press, 1986). pp.99101, discusses the role sex was seen to play in fulfilling the ends of marriage.

5 Davies, "Continuity and Change." p. 73.

6 Angus McLaren. Reproductive Rituals: The Perception of Fertility in England from the Sixteenth to the Nineteenth Centuries (London: Methuen. 1984), p. 45.

7 R. V.Schnucker. "The English Puritans and Pregnancy. Delivery and Breast Feeding." History of Childhood Quarterly. 1 (1974), 637-58: Patricia Crawford, "Attitudes to Menstruation in Seventeenth-Century England," Past \& Present. 91 (1981). 47-73; McLaren, Reproductive Rituals, pp. 69-71. McLaren. p. 69, notes that Gouge advised men to practice sexual restraint while their wives were breast feeding but hesitated to make this "an inviolable law" (Gouge, Of Domestical Duties. [1626], p. 131). The phrase "due benevolence" derives from I Corinthians $7: 3-5$.

8 Davies, "Continuity and Change." p. 73.

9 Ronald Mushat Frye. "The Teachings of Classical Puritanism on Conjugal Love," Studies in the Renaissance. 2 (1955), 156-58.

10 Davies, "Continuity and Change." pp. 58-80; Margo Todd, "Humanists, Puritans and the Spiritualized Household," Church History. 49 (1980), 18-34. Davies and Todd have corrected the false claim. made by earlier scholars, that the Puritan marriage doctrine was original in its recognition of sex as a valid and essential activity between spouses. For the earlier view see, for example. Haller. "The Puritan Art of Love" and Frye, "The Teachings of Classical Puritanism."

11 Davies. "The Sacred Condition of Equality."pp. 573-75, 578. Despite their tolerance of voluntary sexual abstinence in marriage, humanists did not necessarily consider celibacy and virginity superior alternatives. See Todd. "Humanists," pp. 18-19.21; Leites, The Puritan Conscience.pp. 80-82 and John K. Yost. "The Value of Married Life for the Social Order in the Early English Renaissance." Societas. 6 (1976). 25-39.

12 Quoted in Edmund S. Morgan. The Puritan Family, rev. ed. (New York: Harper \& Row, 1966), pp. 62-63.

13 Davies. "Continuity and Change," p. 73; James A. Brundage, "Let Me Count the Ways: Canonists and Theologians Contemplate Coital Positions," Journal of Medieval History, 10 (1984). 81-93; Pierre J. Payer. Sex and the Penitentials (Toronto: University of Toronto Press, 1984); Thomas N. Tentler, Sin and Confession on the Eve of the Reformation (Princeton: Princeton University Press, 1977).

14 [William Heale]. The Great Advocate and Oratour for Women, (1682), p. 7, cited in Davie, "The Sacred Condition of Equality."pp. 574-76. 
15 Thomas Cogan, The Haven of Health (London, 1589), p. 252; William Vaughan, The Natvrall and Artificial Directions for Health (London, 1600), p. 46.

16 Quoted in Audrey Eccles, Obstetrics and Gynaecology in Tudor and Stuart England (Kent. Ohio: Kent State University Press, 1982), p. 36. No reference is provided for this quotation.

17 McLaren, Reproductive Rituals, p. 45.

18 In preparing this essay I have tried primarily to convey a sense of the range of sexual issues found in diaries. I have not tried to be exhaustive in my selection of the diaries themselves. The following works, however, contain extensive bibliographies of diaries and autobiographies. A thorough search through them would yield a fairly comprehensive list of journals - Puritan and otherwise: Elisabeth Bourcier, Les journaux prives en Angleterre de 1600 à 1660 (Paris: Publications de la Sorbonne, 1976), pp. 457-63; Edward G. Cox, A Reference Guide to the Literature of Travel, vol. 3 (Seattle: University of Washington Press, 1949), pp. 608-638; Paul Delany, British Autobiography in the Seventeenth Century (London: Routledge \& Kegan Paul, 1969). pp. 175-85; E. F. MacPike, comp., "English, Scottish and Irish Diaries, Journals, CommonplaceBooks, etc., 1550-1900: A Bibliographical Guide to Selected Material," Bulletin of Bibliography. 17 (1942), 183-85, 213-15; William Matthews, comp., British Diaries: An Annotated Bibliography of British Diaries Written between 1442 and 1942 (Berkeley and Los Angeles: University of California Press, 1950); Sara Heller Mendelson, "Stuart Women's Diaries and Occasional Memoirs," in Women in English Society, ed. Mary Prior (London and New York: Methuen, 1985), pp. 181-210.

Contemporary biographies are also important sources of information about diaries. Many seventeenth-century biographers of clergymen and other devout persons, for instance, had access to their subject's personal journals which have since been lost or destroyed. Extensive lists of biographies can be found in the following two works: William Haller, The Rise of Puritanism (New York: Harper \& Brothers, 1938) and Donald A. Stauffer, English Biography before 1700 (Cambridge, MA.: Harvard University Press, 1930).

19 For an analysis of the spiritual and psychological motives behind diary writing see Haller. Rise of Puritanism, pp. 96-100 and Owen C. Watkins, The Puritan Experience (London: Routledge \& Kegan Paul, 1972), pp. 1-24.

20 Robert Woodforde's Diary, entry for 26 January 1637/8: New College Library, Oxford. MS 9502. I wish to thank the Warden and Scholars of New College, Oxford for their kind permission to publish extracts from Woodforde's diary.

21 John Beadle, The Journal or diary of a Thankfull Christian (London, 1656), p. 55.

22 Woodforde's Diary, entries respectively for 6 November and 18 August 1638. Italics are my own.

23 Ibid. Woodforde's marriage took place on 22 January 1634/5. See entry for 22 January $1637 / 8$. where Woodforde notes "this day I have bene marryed 3 yeares." Woodforde was born on 3 April 1606.

24 Woodforde stops commemorating this temptation after the entry for 16 October 1637.

25 Woodforde laments his attraction to strong drink and tobacco in the following entries: 3 August, 7 September, 6 October, and 6 November 1638.

26 "A Dyurnall or Catalogue of all My Actions and Expences from the 1st of January, 1646-[7]." in Yorkshire Diaries and Autobiographies in the Seventeenth and Eighteenth Centuries, ed. Charles Jackson, Surtees Society, 65 (1875), 55.

27 M.M. Knappen, ed., Two Elizabethan Puritan Diaries (London: Society for Promoting Christian Knowledge, 1933), pp. 103, 110.

28 The Diary of Ralph Josselin, 1616-1683, ed. Alan Macfarlane(London: Oxford University Press, 1976), p. 547. Josselin's wife left for London on 6 May and returned three weeks later. When Josselin made this entry she had been away for over two weeks.

29 Woodforde's Diary, entries for 7 and 9 July 1638.

30 Knappen, Puritan Diaries, pp. 103, 111.

31 The Diary of the Rev. Henry Newcome from September 30, 1661, to September 29, 1663, ed. Thomas Heywood, Chetham Society, 18 (1849), 65, 68, 217. 


\section{2 / Renaissance and Reformation}

32 Levinus Lemnius, The Touchstone of Complexions, trans. Thomas Newton (London, 1576), p. 113.

33 The Journal of George Fox, ed. Norman Penney (London: Dent, 1924), p. 7.

34 The Journal of Richard Norwood, eds. W. F. Craven and Walter B. Hayward (New York: Scholars' Facsimiles \& Reprints, 1945), p. 26.

35 Ibid., pp. 70-71.

36 Ibid., pp. 95-96, 26. We should not rule out the possibility that Norwood may be talking about wet dreams as well as masturbation. Lemnius' description (Touchstone of Complexions, p. 105) of the causes and consequences of erotic dreams in virgins is instructive:

And this thinge is to be obserued and marked in yonge lustye Damselles and Virgins, which remayne long vnmaried, or which by profession of chastitye, are wayned and debarred from Wedlocke .... And hereuppon it is, that sometyme in Imagynation, thinking themselues to lye wyth men by beholding or touchinge of them they be troubled in theyr sleepe with the night Mare, and the effluxions of seede, wherwith they pollute themselues in the nighte season: Hereuppon commeth trembling \& quaking of the heart, by reason of grosse fumes, which inuade the pannicle or coffyn of the heart, called Pericardion, and lye heauely vppon the body pressinge it downe as though they were night Hegges, or Hobbegobblins.

37 Journal of Richard Norwood, pp. 26-27.

38 Norwood's analysis here is consistent with the Protestant position that spiritual or worldly success is freely and undeservedly given by God. Never is it a result of human effort or virtue. Robert Woodforde, like Norwood, is also careful to attribute all blessings to his Saviour (entry for 12 September 1637):

graciously affected in prayer with my wife but especially in private alone, where the Lord did graciously answere me in my poore requestes, and the Lord will surely blesse me, not for my merites (which are no better then sinne) but for his mercyes sake.

39 Journal of Richard Norwood, pp. 70-71; see also pp. 95-6, 102-109. For further discussions of Norwood's struggle with masturbation see: Steven R. Smith, "Religion and the Conception of Youth in Seventeenth-Century England," History of Childhood Quarterly, 2 (1975), 507-508 and Watkins, The Puritan Experience, p. 76.

40 Lawrence Stone, The Family, Sex and Marriage in England, 1500-1800 (New York: Harper \& Row, 1977), pp. 512-517; Eccles, Obstetrics and Gynaecology, p. 34.

41 Hilda Smith, "Gynecology and Ideology in Seventeenth-Century England," in Liberating Women's History, ed. Berenice A. Carroll (Urbana: University of Illinois Press, 1976), p. 104; Stone, Family, Sex and Marriage, p. 512. But see also William Vaughan's Natvrall and Artificial Directions for Health (London, 1600), p. 47, which warned that "Sperme or seed of generation is the one[1]y comforter of nature: which wilfully shed or lost harmeth a man more, then if he should bleed fortie times so much." Vaughan did not necessarily have masturbation in mind when he wrote these words. Their immediate context is one of concern over the ill effects of immoderate sex, or "venerie."

42 Robert Allen, A Treasvrie of Catechisme, or Christian Instrvction (London, 1600), p. 184.

43 Paul S. Seaver, Wallington's World: A Puritan Artisan in Seventeenth-Century London (Stanford, CA.: Stanford University Press, 1985), p. 26.

44 Diary of Ralph Josselin, p. 1.

45 The Life of the Reverend Mr. George Trosse, ed. A. W. Brink (Montreal and London: McGillQueen's University Press, 1974), p. 62.

46 Hill, Society and Puritanism, pp. 217-18,234-41 and "Sin and Society," in The Collected Essays of Christopher Hill, Vol. 2 (Amherst, MA.: University of Massachusetts Press, 1986), pp. 117-25. 
47 Rachel Weigall, "An Elizabethan Gentlewoman: the Journal of Lady Mildmay, circa 15701617," The Quarterly Review, 215 (1911), 120-21.

48 Woodforde's Diary, entry for 11 March 1637.

49 James O. Halliwell, ed., The Autobiography and Correspondence of Sir Simonds D'Ewes, Vol. 1 (London: R. Bentley, 1845), pp. 141-42.

50 For an example of the recording of sexual misbehaviour almost solely for its sensationalist value, see Thomas D. Murphy, ed., "The diary of William Whiteway of Dorchester" (Ph.D. diss., Yale University, 1939), p. 165. On 6 April 1631 Whiteway noted that a special commission had found Mervin Audley, the earl of Castlehaven, guilty "of Sodomy, and of aiding Skipwith his Ganymede to ravish his owne Lady and his sons wife." Castlehaven was beheaded on 14 May. This notorious case is discussed by Caroline Bingham in "Seventeenth-Century Attitudes toward Deviant Sex," Journal of Interdisciplinary History, 1 (1971), 447-68; see also Bruce Mazlish's "Comment" in the same journal.

51 Alan Macfarlane, The Family Life of Ralph Josselin (Cambridge: Cambridge University Press, 1970), p. 83.

52 Puritan moralists recommended - though did not necessarily demand - sexual abstinence and restraint during nursing. See Schnucker, "The English Puritans and Pregnancy, Delivery and Breast Feeding," pp. 637-58.

53 Weigall, “An Elizabethan Gentlewoman,” pp. 120, 125.

54 John Vigon, The Most Excellent Workes of Chirurgerye (London, 1568), p. x.

55 Thomas Laquer, "Orgasm, Generation and the Politics of Reproductive Biology," Representations, 14 (1986), 1-16; Eccles. Obstetrics and Gynaecology, p. 36; McLaren, Reproductive Rituals, pp. 14- L1, 26. McLarel 11yıuy points vul (p. 29) that the iwu-seed tneory losters the false impression that there was total sexual equality between seventeenth-century men and women. In reality, the theory depended on the imposition of the male model of reproduction onto the female anatomy. Ultimately, says McLaren, "male physical and psychological needs were taken as the norm against which women's acts and feelings were measured."

56 McLaren, Reproductive Rituals, p. 20, quotes the following exuberant passage from Lazarus Riverius' The Practice of Physick (London, 1658), p. 503, to illustrate the contemporary belief that in order to conceive, women had to undergo sexual pleasure culminating in orgasm. According to Riverius a woman's womb, during sex, is "skipping as it were for joy" so that she

may meet her Husband's Sperm, graciously and freely receive the same, and draw it into its innermost Cavity or Closet, and withal bedew and sprinkle it with her own Sperm, and powered forth in that pang of Pleasure, that so by the commixture of both, Conception may arise.

57 Keith Thomas, "The Double Standard," Journal of the History of Ideas, 20 (1959), 215.

58 William Turner, The First and Second Parts of the Herbal of William Turner (London, 1568), part 2, p. 70; part 1, p. 167. See also in McLaren, Reproductive Rituals, p. 36.

59 Lady Mildmay's journal is not the only work of its kind to furnish information about ownership of medical treatises. At the end of William Whiteway's seventeenth-century diary, for instance, there is a list of similar books owned by the author. According to this list Whiteway owned at least eleven medical texts, including works by David Herlicius (1557-1636), Laurent Joubert (1529-1583), Giovanni Battista Zapata (b. 1520), and Levinus Lemnius. White possessed a Latin copy of Lemnius' De habitu et constitutione corporis quam Graeci krasin, triviales complexionem vocant (Antwerp, 1561). This work was translated into English by Thomas Newton under the title of The Touchstone of Complexions (London, 1576). See Murphy, ed., "The Diary of William Whiteway," Appendix V, pp. 1-15.

60 Trosse, Life, p. 63. Both Norwood and Trosse talk about having - or wanting to have - illicit sex with women. See Norwood, Journal, p. 60 and Trosse, Life, p. 65.

61 Augustine, Confessions, trans. R. S. Pine-Coffin (Harmondsworth, Middlesex: Penguin Books, 1961), pp. 43-44.

62 Norwood, Journal, pp. 61-62; see also pp. 84-85.

63 Watkins, The Puritan Experience, pp. 59-61, 72-76, 86, 136.

64 Norwood, Journal, p. xxx. 


\section{4 / Renaissance and Reformation}

65 Sa muel Clarke, The Lives of Sundry Eminent Persons in this Later Age (London, 1683), pp. 162-63; see also Clarke's comments on Richard Blackerby. Blackerby kept three diaries: one in Greek. one in Latin, another in English.

66 Elisabeth Bourcier ed., The Diary of Sir Simonds D'Ewes (1622-1624) (Paris: Publications de la Sorbonne, 1974), p. 55.

67 Mendelson. "Stuart Women`s Diaries," pp. 183-84.

68 Katharine Austen, a seventeenth-century widow. prefaced her diary with a similar statement; see Mendelson, "Stuart Women's Diaries," p. 184.

69 Newcome, Autobiography, Vol. 1, p. 154. Rohert Woodforde also uses the word "carnal" several times in his diary to refer to the things of this world. See, for example, entries for 23 November 1637. 4 February 1638, and 28 February 1638.

70 Newcome, Autobiography, vol. 1. p. 154.

71 Christopher Hill. The Experience of Defeat: Milton and Some Contemporaries (New York: Viking. 1984). pp. 295-96 and passim.

72 A Complete Collection of State-Trials, and Proceedings for High-Treason, and Other Crimes and Misdemeanours, 4th ed.. Vol. 1 (London. 1776). pp. 823-950, passim. Laud's diary, along with a large store of his other personal documents, was confiscated by his old enemy. William Prynne; see Hugh R. Trevor-Roper. Archbishop Laud: 1573-1645, 2nd ed (Hamden, CT.: Archon Books. 1963), pp. 418-20.

73 On 21 August 1625 Laud recorded in his diary that he dreamt the Duke of Buckingham "came into bed with me; where he behaved himself with great kindness towards me." Laud denied Prynne's accusations of depravity. See Charles Cotton, "The Dream Life of Archbishop Laud." History Today. 36 (1986), 12.

74 Sanford Brown Meech and Hope Emily Allen eds.. The Book of Margery Kempe, Early English Text Society, original series 212 (London, 1940), pp. 11-12; see also pp. 21, 23-25.

75 Joyce E. Salisbury. "The Latin Doctors of the Church on Sexuality." Jourmal of Medieval History. 12 (1986). 279-89.

76 Book of Margery Kempe. pp. 23-25: see also Yost. "The Value of Married Life." pp. 26-27.

77 James Turner Johnson. A Society Ordained by God: English Puritan Marriage Doctrine in the First Half of the Seventeenth Century (Nashville. TN.: Abingdon Press, 1970), p. 101.

78 A ryght frutefull Epystle by the moste excellent clerke Erasmus in laude and prayse of marrymony. trans. Rychard Tauernour (London, 1532), pp. Ci v, C6 r. For a full discussion of Erasmus' views on marriage and celibacy see Yost. "The Value of Married Life," pp. 29-32.

79 Todd. "Humanists." pp. 32-34.

80 Of Domesticall Dvties (London, 1634), p. 365. Another piece of biblical erotica which Gouge recommends is the Old Testament Song of Songs. Husbands especially, he says, will find this work a "good patterne and president" for their own relationships with their wife. "For nothing is more lovely than a good wife" (p. 366).

81 Frye. "The Teachings of Classical Puritanism." pp. 156-58.

82 Paradise Lost, IV. $11.720-775$.

83 A Good Wife Gods Gift: And A Wife Indeed. Two Marriage Sermons (London, 1623), p. 24. See also Gataker's second sermon "A Wife in Deed," pp. 66-67. 